\title{
GAMBARAN AKTIVITAS FISIK PENDERITA STROKE
}

\author{
Cut Ayu Husnul Khatimah ${ }^{1}$, Mursal ${ }^{2}$, Hayatun Thahirah ${ }^{3}$ \\ ${ }^{1}$ Mahasiswa Program Studi Ilmu Keperawatan, STIKes Muhammadiyah Lhokseumawe, 24300 \\ ${ }^{2}$ Dosen Profesi Ners STIKes Muhammadiyah Lhokseumawe, Indonesia 24300 \\ ${ }^{3}$ Dosen Ilmu Keperawatan STIKes Muhammadiyah Lhokseumawe, Indonesia 24300 \\ *Correspondence: mursal@stikeslhokseumawe,ac.id
}

\begin{abstract}
Insufficient activity is one of the main risk factors for premature death worldwide. People who are less active are 20\%-30\% more likely to die early than those who are moderately active. Insufficient physical activity is a major risk factor for stroke. The purpose of the study was to find out how the description of the physical activity of stroke patients. This research design was using descriptive method. The population in this study were all 32 stroke sufferers. The number of samples in this study were 32 using total sampling technique. This research was carried out on July 25 to July 31 , 2021. The data analysis in this study was processed by a computerized system. The result showed of study, it was found that the physical activity of stroke patients, the majority did physical activity as many as 18 respondents (56.3\%) and did not do physical activity as many as 14 respondents $(43.7 \%)$.
\end{abstract}

Keywords : Physical Activity, Stroke

\begin{abstract}
ABSTRAK
Aktivitas yang tidak mencukupi adalah satu dari faktor risiko utama terhadap kematian dini di seluruh dunia. Orang yang kurang aktif memiliki peluang lebih mungkin sebesar 20\%-30\% untuk meninggal lebih cepat dibandingkan mereka yang cukup aktif. Aktivitas fisik yang tidak mencukupi merupakan faktor risiko utama stroke. Tujuan penelitian untuk mengetahui bagaimanakah gambaran aktivitas fisik penderita stroke. Desain penelitian ini menggunakan metode penelitian deskriptif. Populasi dalam penelitian ini adalah seluruh penderita stroke sebanyak 32 orang. Jumlah sampel dalam penelitian ini sebanyak 32 dengan menggunakan teknik total sampling. Penelitian ini telah dilaksanakan pada tanggal 25 Juli sampai dengan 31 Juli 2021. Analisis data dalam penelitian ini diolah dengan sistem komputerisasi. Berdasarkan hasil penelitian diperoleh bahwa aktivitas fisik penderita stroke mayoritas melakukan aktivitas fisik sebanyak 18 responden $(56.3 \%)$ dan tidak melakukan aktivitas fisik sebanyak 14 responden (43.7\%).
\end{abstract}

Kata Kunci : Aktivitas Fisik, Stroke 


\section{PENDAHULUAN}

Stroke adalah salah satu penyakit kardiovaskuler yang berpengaruh terhadap arteri utama menuju dan berada di otak, stroke terjadi ketika pembuluh darah yang mengangkut oksigen dan gizi menuju otak pecah atau terhambat oleh bekuan sehingga otak tidak mendapat darah yang dibutuhkannya. Jika kejadian berlangsung lebih dari 10 detik akan menimbulkan kerusakan permanen otak (Feigin, 2016).

Berdasarkan World Health

Organization (WHO) (2020), pada tahun 2020, diperkirakan 40 juta kematian terjadi oleh penyakit tidak menular, yaitu $70 \%$ dari total kematian (56 Juta). Mayoritas kematian tersebut disebabkan oleh empat penyakit tidak menular utama. Dari total kematian karena penyakit tidak menular, proporsinya adalah kardiovaskular 45\%, kanker $22 \%$, penyakit pernapasan kronis $10 \%$, dan diabetes 4\%. Dari 56.4 juta kematian di seluruh dunia pada tahun 2020, lebih dari setengah (54\%) disebabkan oleh 10 penyebab teratas. Stroke adalah pembunuh terbesar kedua setelah penyakit jantung iskemik. Penyakit ini tetap menjadi penyebab utama kematian di dunia dalam 15 tahun terakhir (WHO, 2020).

Hasil Riskesdas tahun 2018, prevalensi penyakit stroke di Indonesia meningkat seiring bertambahnya umur. Kasus stroke tertinggi yang terdiagnosis tenaga kesehatan adalah usia 75 tahun keatas $(43,1 \%)$ dan terendah pada kelompok usia 15-24 tahun yaitu sebesar 0,2\%. Prevalensi stroke berdasarkan jenis kelamin lebih banyak laki-laki $(7,1 \%) 2$ dibandingkan dengan perempuan $(6,8 \%)$. Berdasarkan tempat tinggal, prevalensi stroke di perkotaan lebih tinggi $(8,2 \%)$ dibandingkan dengan daerah pedesaan $(5,7 \%)$ (Riskesdas, 2018).

Laporan Dinas Kesehatan Provinsi Aceh (2020), prevalensi stroke di Provinsi Aceh berdasarkan diagnosis tenaga kesehatan sebesar 6,6 per mil dan yang berdasarkan diagnosis tenaga kesehatan atau gejala sebesar 10,5 per mil. Jadi, sebanyak 62,8 persen penyakit stroke telah terdiagnosis oleh nakes. Prevalensi penyakit jantung koroner, gagal jantung, dan stroke terlihat meningkat seiring peningkatan umur responden. Prevalensi stroke pada laki-laki lebih tinggi daripada perempuan (Dinkes Provinsi Aceh, 2020).

Paparan data dari Dinas Kesehatan Bireuen (2020), prevalensi stroke di Kabupaten Bireuen sebanyak 422 kasus stroke yang terdiri dari laki-laki sebanyak 247 kasus dan perempuan sebanyak 175 kasus stroke (Dinkes Bireuen, 2020). Berdasarkan laporan Puskesmas Peusangan jumlah penderita stroke pada tahun 2020 sebanyak 32 kasus stroke (Puskesmas Peusangan, 2020).

Stroke yang menyerang lanjut usia menyebabkan ketergantungan lanjut usia semakin meningkat. Pada lansia terjadinya proses menua yang mengakibatkan kelemahan (impairment), keterbatasan (disability) dan keterlambatan atau ketidakmampuan (handicap) yang akan dialami bersamaan dengan proses kemunduran (Nugroho, 2018).

Penyakit stroke banyak ditemukan pada masyarakat yang berusia 45 tahun ke atas. Stroke terjadi secara mendadak dan dapat berakhir pada kematian serta kecacatan yang permanen pada anggota gerak. Dampak yang ditimbulkan akibat stroke antara lain adalah kelemahan atau kelumpuhan pada ekstremitas anggota gerak serta gangguan penglihatan akibat keterbatasan lapang pandang. Hal ini menyebabkan ketidakmampuan penderita stroke dalam melakukan aktivitas sehari-hari secara mandiri. Mereka menjadi bergantung kepada orang lain di sekitarnya. Hal ini yang menyebabkan kualitas hidup mereka menurun. Faktor kualitas hidup yang paling mempengaruhi lansia pasca stroke adalah 
status fungsional. Dengan meningkatkan fungsi fisik maka diharapkan dapat membantu memberikan kualitas hidup yang lebih baik (Kemenkes Pusdatin, 2014).

Kesembuhan pasien stroke tergantung pada beberapa elemen yaitu jumlah dan lokasi otak yang rusak, kesehatan umum pasien yang bersangkutan, sifat-sifat (personality) dan kondisi emosional pasien. Demikian juga dukungan dari keluarga dan kawan-kawan serta yang terpenting adalah pengobatan yang diterimanya (Pudiastuti, 2018).

Gaya hidup sering menjadi penyebab berbagai penyakit yang menyerang usia produktif, karena generasi muda sering menerapkan pola makan yang tidak sehat dengan seringnya mengkonsumsi makanan tinggi lemak dan kolesterol tapi rendah serat. Selain banyak mengkonsumsi kolesterol, mereka mengkonsumsi gula yang berlebihan sehingga akan menimbulkan kegemukan yang berakibat terjadinya penumpukan energi dalam tubuh (Dourman, 2013).

Aktivitas yang tidak mencukupi adalah satu dari faktor risiko utama terhadap kematian dini di seluruh dunia. Orang yang kurang aktif memiliki peluang lebih mungkin sebesar 20\%-30\% untuk meninggal lebih cepat dibandingkan mereka yang cukup aktif. Aktivitas fisik yang tidak mencukupi merupakan faktor risiko utama penyakit kardiovaskular, kanker, dan diabetes (WHO, 2018).

Tingkat aktivitas fisik dikategorikan cukup apabila seseorang melakukan latihan fisik atau olahraga selama 30 menit setiap hari, atau minimal 3-5 hari dalam seminggu (WHO, 2017). Latihan fisik adalah metode yang efektif untuk meningkatkan fungsi endotel. Peningkatan pelepasan dari substansi vasodilator nitrit oksida dianggap satu mekanisme dimana fungsi endotel ditingkatkan melalui latihan fisik (Kearns, 2017). Aktivitas fisik yang kurang dapat mempengaruhi frekuensi denyut jantung menjadi lebih tinggi sehingga otot jantung harus bekerja lebih keras pada setiap kontraksi. Otot jantung yang bekerja semakin keras dan sering memompa, maka makin besar tekanan yang dibebankan pada arteri sehingga dapat menyebabkan tekanan darah meningkat (Anggara dan Prayitno, 2013).

Penelitian sebelumnya yang dilakukan oleh Audina (2018), dengan judul Hubungan aktivitas fisik dengan kejadian stroke pada penduduk Bogor Tengah tahun 2016. Hasil penelitian ini mendapatkan prevalensi stroke di Kecamatan Bogor Tengah sebesar 15 per 1000 penduduk. Terdapat hubungan aktivitas fisik dengan stroke dengan risiko yang berbeda pada kelompok umur. Pada kelompok umur kurang dari 45 tahun, penduduk dengan aktivitas fisik yang kurang akan berisiko terkena stroke sebesar 5.43 kali lebih tinggi dibandingkan yang mempunyai aktivitas fisik cukup. Pada kelompok umur 45 tahun atau lebih, penduduk dengan aktivitas fisik yang kurang akan berisiko terkena stroke sebesar 1.18 kali lebih tinggi dibandingkan yang mempunyai aktivitas fisik cukup.

Sedangkan penelitian Rika (2017), dengan judul Hubungan Antara Aktivitas Fisik Dan Hiperurisemia Dengan Kejadian Stroke Di RSUD DR. HI. Abdul Moeloek Provinsi lampung tahun 2016. Hasil: Pada penelitian ini menunjukkan distribusi frekuensi responden dengan aktivitas sedang yaitu sebanyak42 responden (73,7\%), kadar ureum normal yaitu sebanyak 37 responden $(64,9 \%)$, mengalami stroke nonhemoragik yaitu sebanyak 34 responden $(59,6 \%)$. Ada hubungan antara aktivitas fisik ( $\mathrm{p}$ value 0,001), hiperurisemia ( $p$ value 0,012) dengan kejadian stroke di RSUD DR. HI. Abdul Moeloek Provinsi Lampung Tahun2016.

Hasil survei awal yang dilakukan oleh peneliti terhadap 10 penderita stroke, terdapat 7 orang masih memerlukan bantuan 
untuk berjalan, mandi, berpakaian buang air besar, dan buang air kecil dan kurang mampu melakukan aktivitas fisik di rumah seperti mencuci, memasak, menyapu dan menyetrika, hal ini disebabkan oleh penderita stoke yang parah sehingga mereka kurang mampu melakukan aktivitas fisik pada kesehariannya. Sedangkan 3 orang lainnya melakukan aktivitas fisik seperti biasanya di rumah seperti jalan kaki, bersepeda, melakukan kegiatan di rumah, karena mereka menganggap aktivitas fisik dapat melancarkan peredaran darah di dalam tubuh.

Berdasarkan latar belakang dan penelitian terkait diatas maka yang menjadi rumusan masalah dalam penelitian ini adalah bagaimana gambaran aktivitas fisik penderita stroke.

\section{METODELOGI}

Dalam rancangan penelitian ini penulis menggunakan metode penelitian deskriptif yaitu suatu metode penelitian yang dilakukan dengan tujuan utama untuk mengetahui gambaran atau deskriptif tentang suatu keadaan secara objektif. Metode penelitian deskriptif digunakan untuk memecahkan atau menjawab permasalahan yang sedang dihadapi pada situasi sekarang.

Populasi dalam penelitian ini adalah seluruh penderita stroke sebanyak 32 orang. Teknik pengambilan sampel dalam penelitian ini adalah Total Sampling yaitu teknik pengambilan sampel dimana jumlah sampel sama dengan populasi. Jumlah sampel dalam penelitian ini seluruh penderita stroke sebanyak 32 orang.

Instrument penelitian yang digunakan dalam penelitian ini berupa kuesioner yang dimodifikasi oleh peneliti. Adapun instrumen dalam penelitian ini adalah sebagai berikut: a. Identitas Responden

Identitas responden adalah yang terdiri dari inisial responden, umur, jenis kelamin, pekerjaan dan pendidikan.

b. Aktivitas Fisik

Kuesioner yang digunakan pada aktivitas fisik berupa 15 pernyataan. Pengukuran aktivitas fisik dengan menggunakan skala guttman, untuk setiap pernyataan penulis membuat score penilaian, jika menjawab "Ya" diberi nilai 1 dan jika menjawab "Tidak" diberi nilai 0 , dengan kategori sebagai berikut:

a. Dilakukan, dengan kategori $\mathrm{x} \geq 10$.

b. Tidak Dilakukan, dengan kategori $\mathrm{x}$ $<10$.

Pengolahan data merupakan proses yang sangat penting dalam penelitian. Oleh karena itu, harus dilakukan dengan baik dan benar. Pengolahan data dilakukan secara manual yaitu melalui tahap:

a. Memeriksa data (Editing)

Peneliti menyeleksi atau memeriksa ulang kelengkapan pengisian kuesioner dari pertanyaan yang ada sehingga tidak ada kuesioner yang terbuang. Kuesioner diurutkan dari no 1 sampai dengan no 32 . Proses ini untuk melihat apakah semua data sudah diisi sesuai petunjuk serta tidak ada kesalahan dalam pengisian kuesioner saat penelitian berlangsung.

b. Pengkodean (Coding)

Setelah semua data yang ada pada kuesioner lengkap, peneliti melakukan coding terhadap semua jawaban atau informasi responden. Peneliti memberikan kode jawaban secara angka atau kode tertentu sehingga lebih mudah dan sederhana pada saat pengolahan data dilakukan. Untuk setiap pernyataan penulis membuat score penilaian, jika menjawab "Ya" diberi nilai 1 dan jika menjawab "Tidak" diberi nilai 0 .

c. Proses pemasukan data (Processing)

Dalam proses ini, peneliti memasukkan data kedalam master tabel. Semua data 
dimasukkan secara cermat dari no 1 sampai dengan no 32. Entri data ini dilakukan dengan mengisi kolom-kolom atau kotak-kotak pada master tabel sesuai dengan jawaban masing-masing. Untuk setiap pernyataan penulis membuat score penilaian, jika menjawab "Ya" diberi nilai 1 dan jika menjawab "Tidak" diberi nilai 0 .

d. Tabulasi (Tabulating)

Peneliti mengelompokkan responden berdasarkan kategori yang telah dibuat untuk variabel yang diukur dan ditampilkan dalam bentuk tabel. Peneliti memisahkan untuk tabel karakteristik responden, analisis univariat supaya lebih mudah dipahami bagi yang membaca.

Analisa data dalam penelitian ini, yaitu analisis univariat yang bertujuan untuk menjelaskan atau mendeskripsikan setiap variable penelitian.

\section{HASIL PENELITIAN}

Tabel 1. Distribusi Frekuensi Karakteristik Responden Berdasarkan Umur $(\mathrm{n}=32)$

\begin{tabular}{|c|c|c|c|}
\hline No & Umur & Frekuensi & Persentase $(\%)$ \\
\hline 1 & $36-45$ tahun & 11 & 34.4 \\
\hline 2 & 46-55 tahun & 14 & 43.8 \\
\hline 3 & 56-65 tahun & 7 & 21.9 \\
\hline & Jumlah & 32 & 100 \\
\hline
\end{tabular}

didapatkan bahwa umur responden berada pada umur 46-55 tahun yang berjumlah sebanyak 14 responden (43.8\%).

Tabel 2. Distribusi Frekuensi Karakteristik Responden Berdasarkan Pekerjaan $(\mathrm{n}=32)$

\begin{tabular}{clcc}
\hline No & Pekerjaan & Frekuensi & Persentase $(\%)$ \\
\hline 1 & Petani & 8 & 25.0 \\
2 & PNS & 5 & 15.6 \\
3 & Pedagang & 6 & 18.8 \\
4 & Pekerja & 4 & 12.5 \\
& Swasta & & 28.1 \\
5 & IRT & 9 & 100 \\
\hline
\end{tabular}

Berdasarkan Tabel 2 diatas, didapatkan bahwa pekerjaan responden mayoritasnya Ibu Rumah Tangga (IRT) yang berjumlah sebanyak 9 responden $(28.1 \%)$

Tabel 3. Distribusi Frekuensi Karakteristik Responden Berdasarkan Pendidikan $(\mathrm{n}=32)$

\begin{tabular}{clcc}
\hline No & Pendidikan & Frekuensi & Persentase $(\%)$ \\
\hline 1 & SD & 5 & 15.6 \\
2 & SMP & 7 & 21.9 \\
3 & SMA & 14 & 43.8 \\
4 & PT & 6 & 18.8 \\
\hline & Jumlah & 32 & 100 \\
\hline
\end{tabular}

Berdasarkan Tabel 3 diatas, didapatkan bahwa pendidikan responden mayoritasnya berada pada pendidikan SMA yang berjumlah sebanyak 14 responden (43. $8 \%)$.

Tabel 4. Distribusi Frekuensi Karakteristik Responden Berdasarkan Jenis Kelamin $(n=32)$

\begin{tabular}{clcc}
\hline No & $\begin{array}{c}\text { Jenis } \\
\text { Kelamin }\end{array}$ & Frekuensi & Persentase \\
\hline 1 & Laki-Laki & 18 & 56.3 \\
2 & Perempuan & 14 & 43.7 \\
\hline & Jumlah & 32 & 100 \\
\hline
\end{tabular}

Berdasarkan Tabel 4 diatas, didapatkan bahwa jenis kelamin responden mayoritasnya berada pada jenis kelamin laki-laki yang berjumlah sebanyak 18 responden $(56.3 \%)$.

Tabel 5. Distribusi Frekuensi Aktivitas Fisik Penderita Stroke $(n=32)$

\begin{tabular}{cccc}
\hline No & Aktivitas Fisik & Frekuensi & $\begin{array}{c}\text { Persentase } \\
(\%)\end{array}$ \\
\hline 1 & Dilakukan & 18 & 56.3 \\
2 & $\begin{array}{c}\text { Tidak } \\
\text { Dilakukan }\end{array}$ & 14 & 43.7 \\
\hline & Jumlah & 32 & 100 \\
\hline
\end{tabular}


Berdasarkan Tabel 5 di atas dapat disimpulkan bahwa aktivitas fisik penderita stroke, responden yang mempunyai aktivitas fisik dilakukan lebih tinggi sebanyak 18 responden (56.3\%), dibandingkan dengan responden yang mempunyai aktivitas fisik tidak dilakukan sebanyak 14 responden (43.7\%).

\section{PEMBAHASAN}

\section{Karakteristik Responden}

Berdasarkan hasil penelitian didapatkan bahwa umur responden berada pada umur 46-55 tahun yang berjumlah sebanyak 14 responden (43.8\%). Hal ini sejalan dengan pendapat Rika (2017), umur responden dapat menjadi salah satu faktor yang berpengaruh dalam melakukan aktivitas fisik karena umur akan berpengaruh terhadap cara pandang, pemikiran dan penilaian. Kemungkinan faktor penyebab hasil tersebut, diantaranya karena memperoleh informasi tentang aktivitas fisik diperkirakan lebih besar pada kelompok usia yang lebih tua.

Pekerjaan responden mayoritasnya IRT yang berjumlah sebanyak 9 responden (28.1\%). Aktivitas fisik penderita stroke juga dipengaruhi oleh pekerjaannya. Kemudahan sarana transportasi dan jenis pekerjaan menyebabkan fisik kurang bergerak secara teratur yang membuat pekerja relatif statis untuk waktu lama, hal tersebut bersama dengan obesitas merupakan faktor risiko utama terjadinya penyakit degeneratif termasuk strok (Audina, 2018).

Pendidikan responden mayoritasnya berada pada pendidikan SMA yang berjumlah sebanyak 14 responden (43. 8\%). Hal tersebut menunjukkan bahwa responden didominasi dengan latar belakang pendidikan yang cukup baik, sehingga memiliki pengetahuan yang baik terkait dengan pelayanan informasi tentang aktivitas fisik penderita stroke. Hal ini tentunya akan mempengaruhi persepsi responden tentang aktivitas fisik penderita stroke. Tingkat pendidikan seseorang juga akan mempengaruhi nilai-nilai yang dianutnya, cara berfikir, cara pandang bahkan persepsinya terhadap suatu masalah (Kearns, 2017).

$$
\text { Jenis kelamin responden }
$$
mayoritasnya berada pada jenis kelamin laki-laki yang berjumlah sebanyak 18 responden $(56.3 \%)$. Hal ini sejalan dengan pendapat Rika (2017), data distribusi jenis kelamin responden menunjukkan bahwa responden dengan jenis kelamin perempuan dan laki-laki hampir berimbang sehingga tidak ada suatu dominasi jenis kelamin tertentu dan diharapkan mampu mewakili keadaan keduanya.

\section{Aktivitas Fisik Penderita Stroke}

Berdasarkan hasil penelitian didapatkan bahwa aktivitas fisik penderita stroke, responden yang mempunyai aktivitas fisik dilakukan lebih tinggi sebanyak 18 responden (56.3\%), dibandingkan dengan responden yang mempunyai aktivitas fisik tidak dilakukan sebanyak 14 responden (43.7\%).

Aktivitas fisik adalah setiap pergerakan tubuh akibat aktivitas otot-otot skelet yang mengakibatkan pengeluaran energi. Setiap orang melakukan aktivitas fisik antara individu satu dengan yang lain tergantung gaya hidup perorangan dan faktor lainnya. Aktivitas fisik terdiri dari aktivitas selama bekerja, tidur, dan pada waktu senggang. Latihan fisik yang terencana, terstruktur, dilakukan berulang-ulang termasuk olahraga fisik merupakan bagian dari aktivitas fisik. Aktivitas fisik sedang yang dilakukan secara terus menerus dapat mencegah resiko terjadinya penyakit tidak menular seperti penyakit pembuluh darah, diabetes, kanker dan lainnya (Kristanti, 2012). 
Kesembuhan pasien stroke tergantung pada beberapa elemen yaitu jumlah dan lokasi otak yang rusak, kesehatan umum pasien yang bersangkutan, sifat-sifat (personality) dan kondisi emosional pasien. Demikian juga dukungan dari keluarga dan kawan-kawan serta yang terpenting adalah pengobatan yang diterimanya (Pudiastuti, 2018).

Aktivitas yang tidak mencukupi adalah satu dari faktor risiko utama terhadap kematian dini di seluruh dunia. Orang yang kurang aktif memiliki peluang lebih mungkin sebesar 20\%-30\% untuk meninggal lebih cepat dibandingkan mereka yang cukup aktif. Aktivitas fisik yang tidak mencukupi merupakan faktor risiko utama penyakit kardiovaskular, kanker, dan diabetes (WHO, 2018).

Tingkat aktivitas fisik dikategorikan cukup apabila seseorang melakukan latihan fisik atau olahraga selama 30 menit setiap hari, atau minimal 3-5 hari dalam seminggu (WHO, 2017). Latihan fisik adalah metode yang efektif untuk meningkatkan fungsi endotel. Peningkatan pelepasan dari substansi vasodilator nitrit oksida dianggap satu mekanisme dimana fungsi endotel ditingkatkan melalui latihan fisik (Kearns, 2017).

Penelitian sebelumnya yang dilakukan oleh Audina (2018), dengan judul Hubungan aktivitas fisik dengan kejadian stroke pada penduduk Bogor Tengah tahun 2016. Hasil penelitian ini mendapatkan prevalensi stroke di Kecamatan Bogor Tengah sebesar 15 per 1000 penduduk. Terdapat hubungan aktivitas fisik dengan stroke dengan risiko yang berbeda pada kelompok umur. Pada kelompok umur kurang dari 45 tahun, penduduk dengan aktivitas fisik yang kurang akan berisiko terkena stroke sebesar 5.43 kali lebih tinggi dibandingkan yang mempunyai aktivitas fisik cukup. Pada kelompok umur 45 tahun atau lebih, penduduk dengan aktivitas fisik yang kurang akan berisiko terkena stroke sebesar 1.18 kali lebih tinggi dibandingkan yang mempunyai aktivitas fisik cukup.

Menurut asumsi peneliti aktivitas fisik yang kurang dapat mempengaruhi frekuensi denyut jantung menjadi lebih tinggi sehingga otot jantung harus bekerja lebih keras pada setiap kontraksi. Otot jantung yang bekerja semakin keras dan sering memompa, maka makin besar tekanan yang dibebankan pada arteri sehingga dapat menyebabkan tekanan darah meningkat.

Berdasarkan hasil penelitian, maka dapat disimpulkan aktivitas fisik penderita stroke, responden yang mempunyai aktivitas fisik baik sebanyak 18 responden (56.3\%), tingkat aktivitas fisik yang teratur dan memadai membantu mengurangi risiko stroke. Aktivitas fisik juga berkontribusi pada pengendalian berat badan, pengendalian stroke, peningkatan tekanan darah dan peningkatan kadar kolesterol dan lipid darah lainnya.

\section{KESIMPULAN}

Berdasarkan hasil penelitian didapatkan bahwa aktivitas fisik penderita stroke, responden yang mempunyai aktivitas fisik dilakukan lebih tinggi sebanyak 18 responden (56.3\%), dibandingkan dengan responden yang mempunyai aktivitas fisik tidak dilakukan sebanyak 14 responden $(43.7 \%)$.

\section{UCAPAN TERIMA KASIH}

a. STIKes Muhammadiyah Lhokseumawe yang telah memberikan izin, ilmu dan arahan dalam melaksanakan penelitian.

b. Pihak Puskesmas yang memberikan izin serta ikut berpartisipasi dalam penelitian ini.

\section{DAFTAR PUSTAKA}

Audina. (2018). Hubungan Aktivitas Fisik Dengan Kejadian Stroke Pada 
Penduduk Bogor Tengah tahun 2016. Jurnal Keperawatan.

Anggara Dwi, F H dan Prayitno N. (2013). Faktor-faktor yang Berhubungan dengan Tekanan Darah di Puskesmas Telaga Murni Cikarang Barat. Jakarta: Program Studi Kesehatan Masyarakat STIKES MH. Thamrin. Jurnal Ilmiah Kesehatan. Vol 5/ No. 1.

Dinkes Aceh, (2020). Angka Kejadian Stroke di Aceh. Banda Aceh: Provinsi Aceh.

Dinkes Aceh Utara, (2020). Angka Kejadian Stroke di Kabupaten Bireuen. Kota Juang: Kabupaten Bireuen.

Puskesmas Peusangan, (2020). Angka Kejadian Stroke di Puskesmas Peusangan. Kota Juang: Kabupaten Bireuen.

Dourman. (2013). Waspadai Stroke Usia Muda. Jakarta : Cerdas Sehat.

Feigin V., (2016). Stroke, Panduan Bergambar Tentang Pencegahan dan Pemulihan Stroke. Jakarta: PT. Bhuana Ilmu Populer pp. 9-20.

Kearns, K. J. (2017). Altered resting-state network connectivity in stroke patients with and without apraxia of speech. NeuroImage: Clinical, 8, 429-439.

https://doi.org/10.1016/j.nicl.2015.0 3.013 .

Kristanti, E.P. (2012). Pengaruh Manajemen Stres Terhadap Stres dan Tekanan Darah Pada Pasien Hipertensi. Tesis. Fak. Psikologi.

Kemenkes Pusdatin. (2014). Profil Kesehatan Indonesia 2014. Jakarta: Pusat Data dan Informasi Kementerian Kesehatan Republik Indonesia.

Nugroho. (2018). Keperawatan Gerontik. Buku Kedokteran EGC: Jakarta.

Riset Kesehatan Dasar (Riskesdas). (2018). Badan Penelitian dan
Pengembangan Kesehatan

Kementerian RI tahun 2018. Diakses dari

http://www.depkes.go.id/resources/d ownload/general/Hasil\%20Riskesda s\%20 2016.pdf.

Rika. (2017). Hubungan Antara Aktivitas Fisik Dan Hiperurisemia Dengan Kejadian Stroke Di RSUD DR. HI. Abdul Moeloek Provinsi lampung tahun 2016. Jurnal Keperawatan.

WHO. (2018). Stroke, Cerebrovascular accident. Stroke. doi:http://www.who.int/topics/cereb rovascular_accident/en/index.html.

WHO. (2020). Diakses 09 Februari 2021: Progres Toward Achieving the Fight Millennium Development Goals.http://www.who.int.com. 